\title{
Merkel Cell Carcinoma cNO TNM Finding v8
}

National Cancer Institute

\section{Source}

National Cancer Institute. Merkel Cell Carcinoma cNO TNM Finding v8. NCI Thesaurus.

Code C136850.

Merkel cell carcinoma without regional lymph node metastasis detected on clinical and/or radiologic examination. (from AJCC 8th Ed.) 